\title{
Activated transcription independent of the RNA polymerase II holoenzyme in budding yeast
}

\author{
J. Bryan McNeil, ${ }^{1,2}$ Helga Agah, ${ }^{1}$ and David Bentley ${ }^{1,3}$ \\ ${ }^{1}$ Amgen Institute, Ontario Cancer Institute, Toronto, Ontario M 5G 2C1, Canada
}

\begin{abstract}
We investigated whether the multisubunit holoenzyme complex of RNA polymerase II (Pol II) and mediator is universal ly required for transcription in budding yeast. CCTD Pol II lacking the carboxy-terminal domain of the large subunit cannot assemble with mediator but can still transcribe the C U P1 gene. C U P1 transcripts made by $\triangle$ CTD Pol II initiated correctly and some extended past the normal poly(A) site yielding a novel dicistronic mRNA. Most C U1 transcripts made by $\triangle$ CTD Pol II were degraded but could be stabilized by deletion of the XR N 1 gene Unlike other genes, transcription of C U P1 and H SP82 also persisted after inactivation of the CTD kinase Kin28 or the mediator subunit Srb4. The upstream-activating sequence (UAS) of the C U P1 promoter was sufficient to drive $\mathrm{Cu}^{2+}$ inducible transcription without Srb4 and heat shock inducible transcription without the CTD. We conclude that the Pol II holoenzyme is not essential for all UAS-dependent activated transcription in yeast.
\end{abstract}

[Key Words: RNA Pol II holoenzyme; CTD; transcriptional activation]

Received May 18, 1998; revised version accepted June 25, 1998.

RNA polymerase II (Pol II) holoenzymes containing core polymerase and many accessory protei ns have been identified in budding yeast (Thompson et al. 1993; Kim et al. 1994; Koleske and Young 1994) and in mammals (Ossipow et al. 1995; Maldonado et al. 1996; Pan et al. 1997). In yeast up to $50 \%$ of Pol II is bound to a complex of $\sim 20$ proteins called mediator (Kim et al. 1994; Myers et al. 1998). Addition of mediator to core Pol II in vitro elevates basal transcription and permits stimulation of transcription in response to activators (Kim et al. 1994; Koleske and Young 1994). In addition to the mediator, holoenzyme has also been isolated in association with other proteins including TFIIB, TFIIF, TFIIH, and Swi/ Snf (Koleske and Young 1994; Wilson et al. 1996).

Several lines of evidence suggest that the carboxy-terminal domain (CTD) of the Pol II large subunit is essential for the physical and functional integrity of the holoenzyme. Purified mediator binds to the CTD (Myers et al. 1998) and the Pol II-mediator complex is disrupted by a monoclonal antibody against the CTD (Kim et al. 1994). Furthermore, addition of mediator to Pol II lacking the CTD did not stimulate either basal or activated transcription (M yers et al. 1998). The CTD is composed of a repeated heptad sequence whose consensus (YSPTSPS)

\footnotetext{
${ }^{2}$ Present address: Ontario Cancer Institute, Toronto, Ontario M5G 2 M9 Canada.

${ }^{3}$ Corresponding author. Present address: Department of Biochemistry and Molecular Genetics, University of Colorado Health Sciences Center, Denver, Colorado 80262 USA.

E-MAIL bentley_d@defiance.uchsc.edu; FAX (303) 315-8215.
}

is absolutely conserved between yeast and mammals. TheCTD undergoes a cycle of hyperphosphorylation and dephosphorylation that accompanies the transcription cycle (Dahmus 1996) and may be linked to recycling of the mediator (Svejstrup et al. 1997). Mediator also strongly stimulates CTD phosphorylation by the Kin28 kinase subunit of TFIIH (Kim et al. 1994). It has been suggested that phosphorylation of the CTD counteracts a negative effector of transcription in crude extracts $(\mathrm{Li}$ and Kornberg 1994) and that it enhances transcriptional el ongation (O'Brien et al. 1994; Lee and Greenleaf 1997). Truncation of the yeast CTD from 26 to between 13 and 11 repeats causes cold and temperature sensitivity for growth and further deletion to 10 or fewer repeats is lethal ( $N$ onet et al. 1987b; West and Corden 1995). $\mathrm{N}$ ine SRB (suppressor of RNA pol B) genes were identified, which as mutants suppressed the cold-sensitive phenotype associated with CTD truncation (N onet and Y oung 1989; Hengartner et al. 1995). Both dominant and recessive srb mutants were obtained, implying that both gain and loss of Srb function can suppress the effects of CTD truncation. The three essential SRB genes, SRB-4, SRB-6, and SRB-7, all encode subunits of the mediator (Thompson et al. 1993; Kim et al. 1994; M yers et al. 1998).

Holoenzyme but not core Pol II is able to respond to activators in a defined transcription system in vitro (Kim et al. 1994; Koleske and Young 1994). Moreover, artificial tethering of holoenzyme subunits to promoters in vivo can activate transcription (Farrell et al. 1996) and CTD truncation mutants have a reduced response to 
some activators (Allison and Ingles 1989; Scafe et al. 1990; Liao et al. 1991; Gerber et al . 1995). On the basi s of these observations it has been suggested that activators work by making protein-protein contacts that recruit holoenzyme to the promoter (Ptashne and Gann 1997). It is not known, however, whether all activators work by this mechanism.

The role of the holoenzyme in vivo has been addressed genetically in yeast. Mutations that inactivate Srb4, Srb6, and Kin28 abolish synthesis of stable mRN As from most genes (Cismowski et al. 1995; Thompson and Young 1995; Valay et al. 1995). On the other hand, the principal effect of mutations affecting the nonessential holoenzyme components Srb8-11, Rox3, Sin4, and Gal 11 is to derepress a particular subset of genes (Carlson 1997). One limitation of these genetic studies is that it is not known how extensively the various mutations disrupt holoenzyme structure in vivo.

We have studied the role of holoenzyme in mRNA synthesis by asking what happens when the CTD is deleted completely. Deletion of the CTD is expected to prevent interaction of core Pol II with mediator and therefore, to preclude assembly of holoenzyme. Pol II without the CTD is capable of transcription in vitro from certain promoters in partially purified systems (Zehring and Greenleaf 1990; Kang and Dahmus 1993; Li and Kornberg 1994), but its function in vivo has not been investigated. We examined transcription in a yeast strain where the only functional Pol II at the restrictive temperature lacks the CTD. Run-on transcription in permeabilized cells (Elion and Warner 1986) was used to measure the average density of polymerases engaged on a gene at a particular instant. Surprisingly, we found that the Pol II minus the CTD was able to transcribe the CUP1 gene at a high level. The holoenzyme subunits Srb4 and Kin28 were also found not to be essential for CUP1 transcription. These results show that in some circumstances, activated Pol II transcription in vivo can occur independently of the "core + mediator" form of holoenzyme.

\section{Results}

A strategy to study transcription in vivo by CTD-deleted Pol II

To determine whether Pol II could function in vivo without the CTD, we introduced a plasmid pFL38rpb1 $\triangle$ CTD, which expresses the large subunit with a deletion of the CTD, into a yeast strain (Y260) with a temperature-sensitive mutation in the RPB1 gene (rpb1-1; $\mathrm{N}$ onet et al. 1987a). When this strain is shifted to $37^{\circ} \mathrm{C}$, the full-length large subunit is inactivated within 5-15 min ( $N$ onet et al. 1987a) and the only potentially functional Pol II is the one that has incorporated the CTDdeleted large subunit. Because there is only one copy of the large subunit in each Pol II complex (Kolodziej et al. 1990), interallelic complementation is highly unlikely. More than $99.9 \%$ of cells in each culture were temperature sensitive, eliminating the possibility of contamina- tion by recombinants between the rpbl-1 and rpbl $\Delta$ CTD alleles. As controls, the Y260 strain was also transformed with vector pFL38 (Bonneaud et al. 1991) or pFL38-RBP1, which expresses the wild-type Rpb1 protein and complements the temperature-sensitive phenotype. The pFL38-rpb1 $\Delta$ CTD plasmid slowed growth of the cells signi ficantly. Doubling times for strai ns harboring pFL38, pFL38-RPB1, and pFL38-rpb1 $\triangle \mathrm{CTD}$ at $30^{\circ} \mathrm{C}$ were 6,4 , and $9.5 \mathrm{hr}$, respectively. Therefore, expression of the CTD-deleted large subunit has a dominant negative effect on growth.

\section{A new CUP1 mRNA transcribed by $\triangle$ CTD Pol II}

Expression of several genes was examined in these derivatives of $\mathrm{Y} 260$ by Northern blot of RNA isolated at intervals after shifting the cells to the restrictive temperature. The steady-state mRNA levels for CUP1, CYH2, SSA 1, and ACT 1 decayed in pFL38 vector-transformed cells at $37^{\circ} \mathrm{C}$ (Fig. $1 \mathrm{~A}$, lanes $1-5$ ) as expected when Pol II is inactivated. In contrast, Y260 containing the pFL38-RPB1 plasmid at $37^{\circ} \mathrm{C}$ behaved likewild type. The cells maintained high ACT1 mRN A, induced CUP1 (Silar et al. 1991) and SSA 1 mRNA, and transiently repressed CYH 2 mRN A in response to heat shock (Fig. 1A, lanes 6-10). In rpbl $\triangle$ CTD-expressing cells, ACT1, CYH2, SSA 1, and CUP1 mRNAs decayed with similar kinetics to the pFL38 vector control (Fig. 1A, lanes 1115). Therefore, Pol II without a CTD is unable to sustain wild-type levels of these mRN As. We noticed, however, that although the major 0.6-kb CUP1 mRN A decayed in cells with pFL38-rpb $1 \Delta \mathrm{CTD}$ at $37^{\circ} \mathrm{C}$, a new $1.7-\mathrm{kb}$ CUP1 transcript was induced transiently after 30-60 $\mathrm{min}$ at the restrictive temperature (see arrow Fig. 1A, lanes 13,14). Synthesis of the 1.7-kb CUP1 transcript was observed in two different rpbl-1 strains harboring the pFL38-rpb1 $\Delta$ CTD plasmid and therefore, is not peculiar to a particular genetic background (data not shown). It is highly unlikely that this transcript is made by a polymerase other than $\triangle C T D$ Pol II because it is expressed at a significant level only in rpb1-1 strains containing the pFL38-rpb1 $\Delta$ CTD plasmid and not in cells with the vector or pFL38-RPB1 (Fig. 1A). The induction of a new CUP1 transcript at $37^{\circ} \mathrm{C}$, which is specific to strains with pFL38-rpb1 $\Delta$ CTD, suggests that Pol II without the CTD has some transcriptional activity in vivo.

The 1.7-kb CU P1 transcript made by $\triangle$ CTD Pol II was characterized in detail. The CU P1 locus is a 2.0-kb tandem repeat that is reiterated up to 15 times (Karin et al. 1984). The repeat contains two ORFs, CUP1 and YHR54C, which are 460 bp apart and transcribed in the same di rection (Fig. 1D). The CU P1 gene, which encodes a metall othionein homolog, has a high basal level of expression and is inducible by heat shock and copper ions (Thiele and Hamer 1986; Silar et al. 1991; Yang et al. 1991). Like other genes transcribed by Pol II, basal and induced CUP1 transcription were inhibited by a mutation of TATA-binding protein (TBP), which is defective for interaction with TFIIA (Stargell and Struhl 1995). 
Figure 1. Synthesis of a novel CU P1 transcript by $\triangle$ CTD Pol II. (A) Northern blots of mRNA from rpbl-1ts strains at intervals after shifting to the restrictive temperature of $37^{\circ} \mathrm{C}$. Strain Y 260 was transformed with pFL38 vector (lanes 1-5), pFL38-RPB1 (lanes 6-10), or pFL38rpb1 $\triangle$ CTD (Ianes 11-15). N ote the appearance of a new 1.7-kb CU P1 transcript specific to the rpb1 $\Delta$ CTD strain. (B) $5^{\prime}$ and $3^{\prime}$ end mapping of CU P1 transcripts. RN ase protection analysis with antisense probes A (lanes 1,2), B (lanes 3,4), and G (lanes 5,6; see D) of RNA from Y 260 containing pFL38 grown at $30^{\circ} \mathrm{C}$ (vector; lanes $1,3,5$ ) or pFL38-rpb1 $\triangle$ CTD grown for $1 \mathrm{hr}$ at $37^{\circ} \mathrm{C}$ ( $\triangle$ CTD; lanes $\left.2,4,6\right)$. N ote that CU P1 RNAs have identical $5^{\prime}$ ends in the two samples (arrowhead; lanes 1,2), but the $\triangle$ CTD Pol II-expressing cells have transcripts that extend past the normal poly(A) site (arrowheads; lane 4). Multiple bands
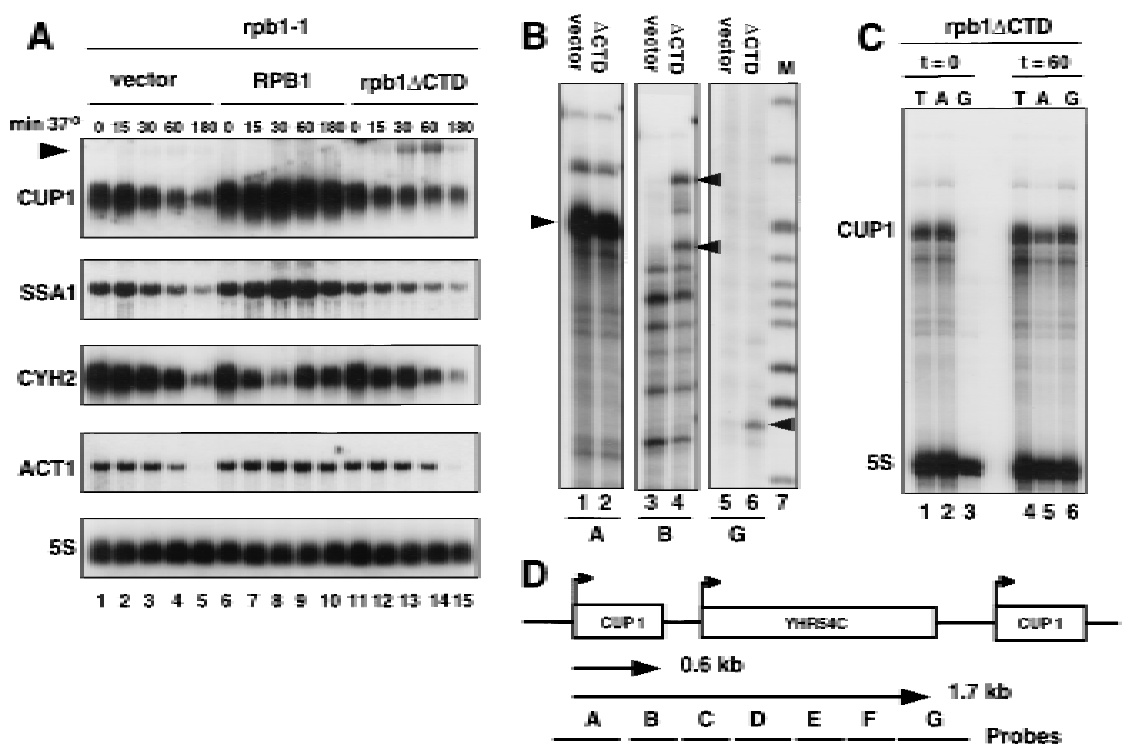

in lane 3 are attributable in part to artifactual cleavage at AU rich regions in probe $B$. The $3^{\prime}$ ends of the readthrough RN As map to the end of the YHR54C ORF (arrowhead; lane 6). Markers (M, lane 7) are Mspl cut pBR322 from 427-123 bp. (C) $5^{\prime}$ end mapping of hybrid sel ected transcripts from the CU P1 locus in pFL38-rpb1 $\triangle \mathrm{CTD}$ cells grown at $30^{\circ}$ ( $\mathrm{t}=0$, lanes $1-3$ ) and for $60 \mathrm{~min}$ at $37^{\circ} \mathrm{C}$ ( $\mathrm{t}=60$; lanes 4-6). Total RN A (T; lanes 1,4) and RN A hybrid sel ected with a 5S rDN A and either CUP1 A or G (see D) were analyzed by RN ase protection with probes for $5 \mathrm{~S}$ rRN A and the CUP1 $5^{\prime}$ end (probe A). N ote that only at $37^{\circ} \mathrm{C}$ (lane 6) did transcripts homologous to region $\mathrm{G}$ appear and their $5^{\prime}$ ends were identical to those of normal CU P1 transcripts made at $30^{\circ} \mathrm{C}($ lanes 1,2$)$. (D) M ap of the CU P1 repeat unit with $0.6-$ and $1.7-\mathrm{kb}$ transcripts and fragments A-G indicated.

YHR54C gene is an ORF of unknown function that is normally expressed at a lower level than CU P1 (Karin et al. 1984). To map the ends of the 1.7-kb CUP1 transcripts produced by $\triangle$ CTD Pol II, we conducted RN ase protection experiments with a series of seven antisense probes $(A-G)$, which covers completel y the CU P1 repeat. RNA samples used in Figure $1 A$ from $Y 260$ cells containing either pFL38 vector at $30^{\circ} \mathrm{C}$ (lane 1 ) or pFL38rpb1 $\triangle$ CTD after $1 \mathrm{hr}$ at $37^{\circ} \mathrm{C}$ (lane 14) were analyzed. CU P1 $5^{\prime}$ ends mapped by probe A did not differ between the control and $\triangle$ CTD Pol II-expressing cells (arrowhead, Fig. $1 B$, lanes 1,2 ). In contrast, mapping with probe $B$ showed that a significant fraction of transcripts read through the CUP1 poly(A) site in rpb1 $\triangle$ CTD-expressing cells (arrowheads, Fig. 1B, lane 4) but not in the control. Antisense probes $\mathrm{C}-\mathrm{F}$ were fully protected by transcripts from rpb1 $\triangle$ CTD-expressing cells, but no protection was observed in the control (data not shown). The $3^{\prime}$ end of the $\triangle C T D$ Pol II transcripts, which traverse the entire CU P1 repeat unit, was mapped to a site $\sim 150$ bp downstream of the YHR54C termination codon (probe G; see arrowhead Fig. 1B, lane 6). Therefore, these RN ase protection results are entirely consistent with the $1.7-\mathrm{kb}$ estimated length of the novel transcript detected by $\mathrm{N}$ orthern blot in Figure $1 \mathrm{~A}$ (lanes 13,14).

To map the start site of the $3^{\prime}$ extended CUP1 transcripts unambi guously, first they were purified by hybrid selection. RNA was isolated from cells with pFL38rpbl $1 \triangle \mathrm{CTD}$ at $30^{\circ} \mathrm{C}(\mathrm{t}=0)$ or after $1 \mathrm{hr}$ at $37^{\circ} \mathrm{C}(\mathrm{t}=60)$ and hybridized to singl e-stranded $M 13$ clones of fragments $A$ or G (Fig. 1D). As a control for recovery, $5 S$ rRN A was also hybrid selected. Selected RNA and total RNA (T) were analyzed by RNase protection with the CUP1 5' probe $A$ and with a $5 S$ probe (Fig. 1C). This experiment provides independent confirmation that the long CU P1 transcripts, which hybridize to fragment $G$, are specific to rpb1 $\triangle C T D$-expressing cells at the restrictive temperature (Fig. 1C, cf. lane 3 with lane 6 ) and that their $5^{\prime}$ ends map to the correct start sites in the CU P1 promoter. In summary, the 1.7-kb transcript is a dicistronic mRNA that starts at the CUP1 promoter and continues to the $3^{\prime}$ end of the downstream gene (YHR54C) where it is cleaved and polyadenylated (data not shown). The specific induction of this new transcript in rpb1 $\Delta$ CTD-expressing cells at the restrictive temperature suggests that Pol II without a CTD recognizes the CU P1 promoter and correctly initiates transcription in vivo. The precise coincidence of the start sites for the $\triangle C T D$-specific $1.7-\mathrm{kb}$ RNA and the normal 0.6-kb RN A makes it very unlikely that the former is made by nonspecific Pol II initiation or by another RNA polymerase.

\section{Run-on analysis of CTD-independent} CUP1 transcription

Steady-state RN A measurements are not reliable indicators of transcription rate because they are influenced by mRN A stability. Furthermore, after shifting cells to the restrictive temperature, new synthesis may be obscured by persistence of mRNAs synthesized before the shift. To obtain instantaneous measurements of polymerase density over CUP1, run-on assays (Elion and Warner 1986) were conducted in cells permeabilized with Sarkosyl, which prevents initiation of transcription. In these 
experiments, ${ }^{32} \mathrm{P}-U \mathrm{UP}$-labeled nascent transcripts from equal numbers of cells were hybridized to slot-blotted strand-specific M13 probes. When the control rpb1-1 strain DBY 120 with pFL38 vector was shifted to $37^{\circ} \mathrm{C}$ for $1 \mathrm{hr}$, polymerase density over the CU P1 repeat unit declined sharply, although a residual background of transcription was detected (Fig. 2A, Iane 2 ). In contrast, cells with the wild-type RPB1 plasmid maintained a high polymerase density over CUP1 at $37^{\circ} \mathrm{C}$ (Fig. 2A, lane 4). Remarkably, polymerase density was approximately equally high over the $5^{\prime}$ end of the CUP1 gene in cells containing pFL38-rpb1 1 CTD after $1 \mathrm{hr}$ at $37^{\circ} \mathrm{C}$ (Fig. 2A, cf. Iane 2 with lane 6 , and 2B). Similar results were obtained after $3 \mathrm{hr}$ at $37^{\circ} \mathrm{C}$ (data not shown). $\triangle \mathrm{CTD}$ Pol II is almost certainly responsi ble for this run-on transcri ption at the restrictive temperature because it is dependent on the rpb1 $\triangle$ CTD gene. These experiments do not address what fraction of CUP1 transcription is carried out by $\triangle$ CTD Pol II at the permissive temperature where presumably it competes with wild-type Pol II. The ratio of 5'-to-3' polymerase densities on the CUP1 gene at the restrictive temperature was al ways higher for $\triangle C T D$ Pol II than for wild-type Pol II (Fig. 2A,B; cf. CUP1-A and CU P1-B in lanes 4 and 6). This observation is consistent with CTD-mediated enhancement of transcriptional elongation (Akhtar et al. 1996; Lee and Greenleaf 1997). The distribution of polymerases on the CU P1 gene suggests that transcripts made by wild-type and $\triangle$ CTD Pol II terminate normally in the region between probes $B$ and C (Fig. 2A, lane 6, and 2B). Apparently the dicistronic readthrough RNA is a relatively small fraction of total transcripts made by the truncated Pol II. In some experiments, significant run-on signals for ENO2, ACT1, and CYH 2 were al so detected in cel Is expressing $\triangle$ CTD Pol II at $37^{\circ} \mathrm{C}$. Unlike CUP1, however, the signals relative to background in the pFL38 vector control varied consider- ably between different experiments. Therefore, we chose to concentrate on CTD-independent transcription of CUP1.

The CUP1 promoter is sufficient for CTD-independent transcription

Because the normal CUP1 start sites are used by $\triangle$ CTD Pol II (Fig. 1C, lane 6), we investigated whether the mutant polymerase could also support transcription of a heterologous gene under the control of the CUP1 promoter. The CU P1 promoter was inserted upstream of a lacZ-zeor fusion gene with the CYC1 $3^{\prime}$ processing site in the plasmid pRS314 CUP1-IacZ-CYC1 (Fig. 2C). This promoter fragment ( -394 to +37 relative to the major start site) includes the CUP1 upstream-activating sequence (UAS) with binding sites for Acel and HSF transcription factors (Silar et al. 1991). Polymerase density over the lacZ reporter gene was consistently higher in the pFL38-rpb1 $\Delta$ CTD-containing strain than in the vector control at $37^{\circ} \mathrm{C}$ (Fig. $2 \mathrm{~A}$, cf. lane 2 with lane 6). No run-on signal was observed for the lacZ or CYC1 probes in strains without the reporter plasmid (Fig. 5A, lane 4). In summary, these results show that the CU P1 promoter is sufficient to support CTD-independent transcription of a lacZ reporter gene.

\section{CUP1 transcripts made by $\triangle$ CTD Pol II are unstable}

The run-on experiments showed high transcriptional activity of $\triangle$ CTD Pol II on the CU P1 gene at $37^{\circ} \mathrm{C}$ (Fig. 2A, lane 6) yet the steady-state level of the major $0.6-\mathrm{kb}$ mRNA species decayed at this temperature (Fig. 1A, lanes $11-15)$. The failure to accumulate $0.6-\mathrm{kb}$ transcripts could be attributable to the specific degradation of transcripts made by $\triangle$ CTD Pol II. This hypothesis was

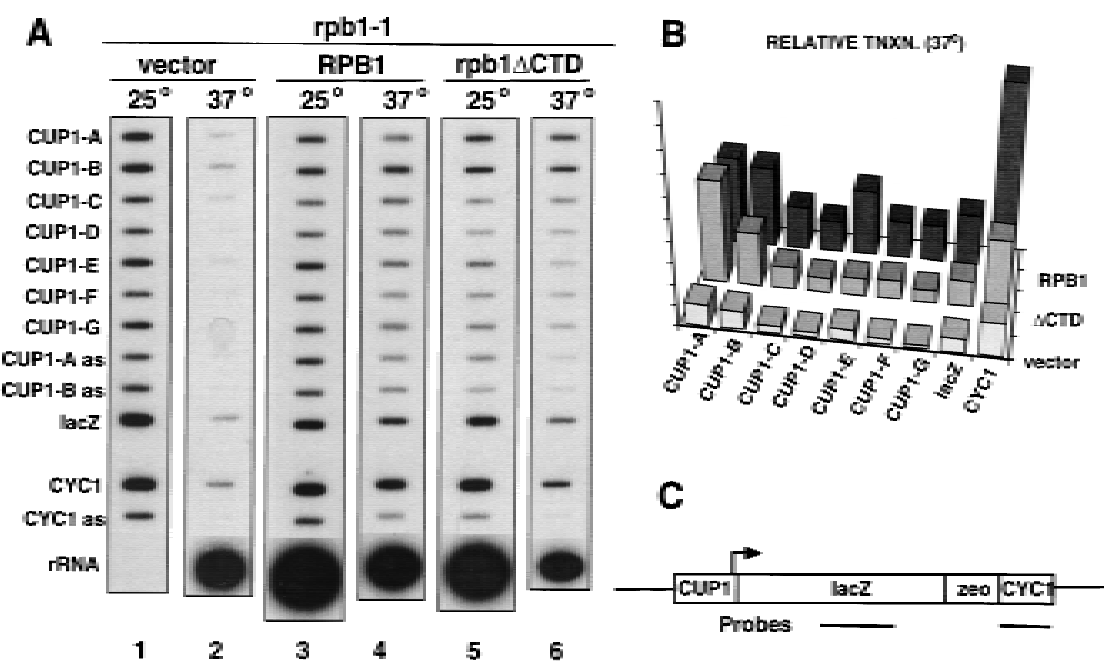
Quantitation of run-on signals at $37^{\circ} \mathrm{C}$. Phosphorlmager signals were normalized for cell number and corrected for $\mathrm{U}$ content. $\mathrm{N}$ ote that Pol I transcription of 35S rRN A fell by four- to eightfold in all heat-shocked cells. The apparent build up of polymerases over the downstream CYC1 sequence relative to lacZ could indicate polymerase stalling at the $3^{\prime}$ end of this gene. (C) Map of the CUP1IacZ-CYC1 fusion gene with IacZ and CYC1 M 13 probes indicated.
Figure 2. Run-on analysis of CUP1 transcription by $\triangle$ CTD Pol II. (A) DBY 120 (rpb11) was transformed with pRS314 CUP1lacZ-CYC1 and either pFL38 vector (lanes 1,2), pFL38-RPB1 (lanes 3,4), or pFL38rpb1 $\triangle$ CTD (lanes 5,6). Cells were harvested at $25^{\circ} \mathrm{C}$ or after $60 \mathrm{~min}$ at $37^{\circ} \mathrm{C}$. [ [2 P]UTPlabeled run-on transcripts were hybridized to single-stranded M 13 clones of fragments A-G from the CUP1/YHR54C repeat unit (Fig. 1D). IacZ and CYC1 clones are shown in C. (as) Antisense controls. The $U$ content of transcripts hybridizing to each probe are CUP1A 56, CUP1-B 105, CUP1-C 117, CUP1-D 118, CUP1-E 70, CUP1-F 79, CUP1-G 138, IacZ 166, and CYC1 99. The rRN A probe was omitted from lane 1 . $N$ ote the transcription by $\triangle \mathrm{CTD}$ Pol II at $37^{\circ} \mathrm{C}$ (lane 6) relative to the vector control (Iane 2). Autoradiography was for 3.5 days. (B) 
tested by analyzing CU P1 transcripts made by $\triangle C T D$ Pol II in a rpb1-1, $\Delta$ xrn1 double mutant. Deletion of XRN 1, which encodes a 5'-to-3' RNA exonuclease, stabilizes uncapped Pol II transcripts that would normally be rapidly degraded (Hsu and Stevens 1993). RN A was isolated from the double mutant strain (DBY121) containing either pFL38, pFL38-RPB1, or pFL38-rpb1 $\triangle$ CTD at intervals after shifting to $37^{\circ} \mathrm{C}$ and anal yzed by $\mathrm{N}$ orthern blot (Fig. 3). After $10 \mathrm{hr}$ at $37^{\circ} \mathrm{C}$, the 0.6-kb CU P1 mRN A had decayed completely in the pFL38 vector control (Fig. 3, Ianes 1-6), but it remained at a constant level in cells expressing rpb1 $\triangle C T D$ (Fig. 3, lanes 13-18). Although transcription by $\triangle C T D$ Pol II maintained a steady level of CUP1 mRNA for a long period in the $\Delta$ xrn1 background, it did not support the approximately threefold induction in response to heat shock that occurred in the RPB1 strain (Fig. 3, lanes 7-12). Failure to induce the RNA could be attributable to inefficient transcriptional elongation (see Fig. 2B, cf. CUP1-A and CUP1-B) by $\triangle C T D$ Pol II or to degradation of the transcripts by an XRN 1-independent pathway. The shortening of CUP1 RN As with time at $37^{\circ} \mathrm{C}$ (Fig. 3, lanes 7-12 and 13-18) is presumably attributable to $3^{\prime}-5^{\prime}$ degradation ( $\mathrm{Hsu}$ and Stevens 1993). In contrast to the 0.6-kb transcript, the 1.7-kb dicistronic CUP1 RN A was not greatly stabilized by XRN 1 deletion (data not shown). In summary, the experiments in Figures 1-3 show that at the restrictive temperature, the 0.6-kb CUP1 transcript is synthesized by $\triangle$ CTD Pol II, but does not accumulate unless it is stabilized by inactivating Xrn1. These results provide an explanation for the high transcription rate measured by run-on experiments without a corresponding high level of CUP1 mRNA. We conclude that a major effect of CTD deletion on CUP1 expression is to cause the transcripts to be unstable.

\section{CUP1 transcription independent of Kin28}

As CUP1 transcription does not absolutely require the CTD, we hypothesized that the CTD kinase Kin28 may

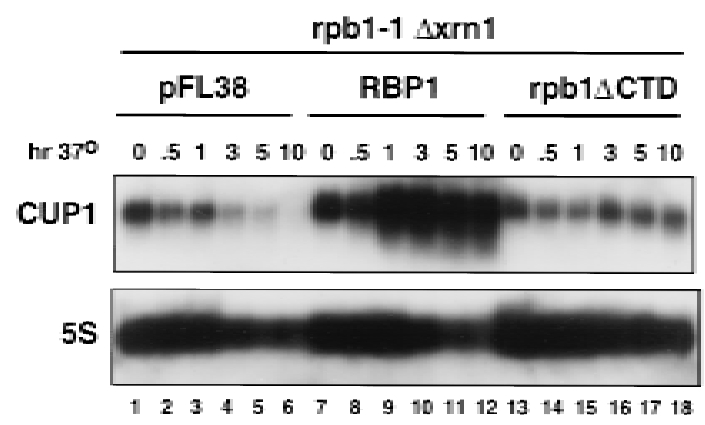

Figure 3. Inactivation of XRN1 stabilizes CUP1 transcripts made by $\triangle C T D$ Pol II. N orthern bl ot of $0.6 \mathrm{~kb} C U P 1$ mRN A and $5 S$ rRN A loading control in strain DBY 121 (rpb1-1, $\Delta \times$ rn1) containing pFL38 vector (lanes 1-6), pFL38-RPB1 (lanes 7-12), or pFL38-rpb1 $\triangle$ CTD (lanes 13-18). RN A was isolated at intervals after shifting to $37^{\circ} \mathrm{C}$ as indicated. N ote the persistance of the 0.6-kb CUP1 transcript in the rpb1 $\triangle$ CTD strain.
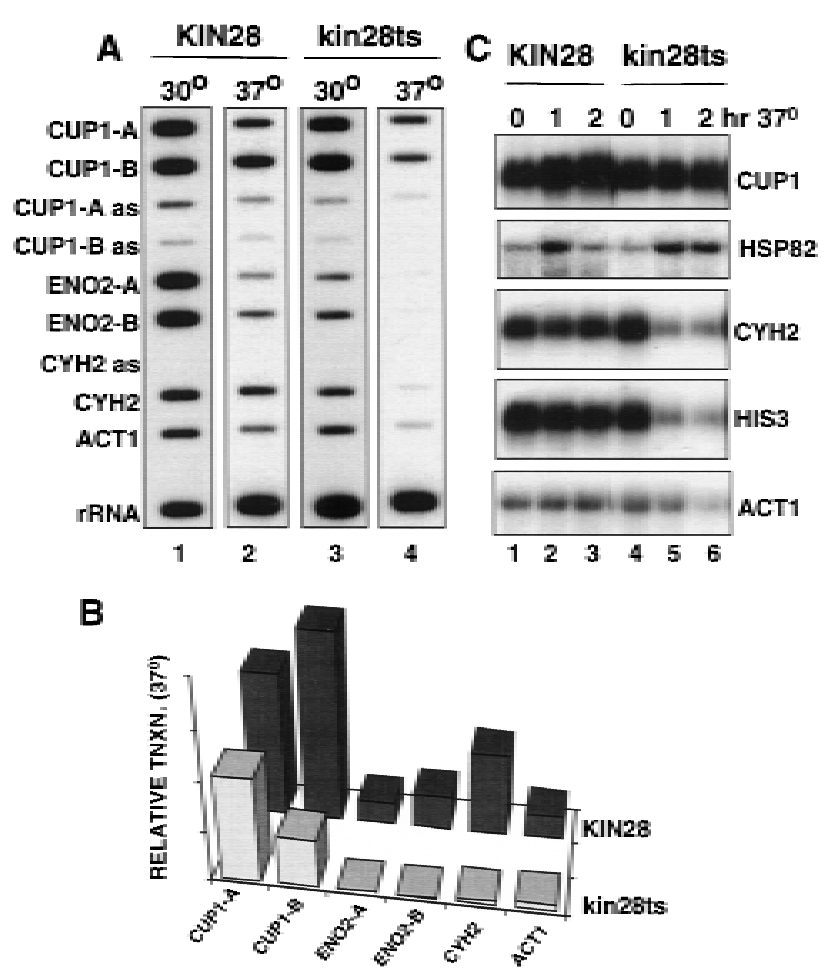

Figure 4. Kin28-independent transcription of CUP1 and HSP82. (A) Run-on analysis in isogenic KIN28 (GFY262, lanes 1,2 ) and kin28ts3 (lanes 3,4 ) strains at $30^{\circ} \mathrm{C}$ and after $1 \mathrm{hr}$ at $37^{\circ} \mathrm{C}$. $\mathrm{U}$ contents of the transcripts hybridizing to the $\mathrm{M} 13$ probes are CUP1A 56, CUP1-B 105, EN O2-A 106, EN O2-B 114, CYH 2 88, ACT 1 153. Autoradiography of lanes 2 and 4 was for approximately twice as long as for lanes 1 and 3. (B) Quantitation of run-on signals at $37^{\circ} \mathrm{C}$. Phosphorlmager signals were normalized as in Fig. 2B. (C) Northern blots of mRNA from KIN 28 (GFY262, lanes 1-3) and kin28ts3 strains (lanes 4-6) at $30^{\circ} \mathrm{C}$ and after 1 and $2 \mathrm{hr}$ at $37^{\circ} \mathrm{C}$. N ote the induction of HSP82 mRNA after heat shock in the kin28ts3 cells.

also be dispensable. To test this idea, we used a kin28ts mutant that at $37^{\circ} \mathrm{C}$ causes al most immediate decay of many mRN As (Cismowski et al. 1995; Valay et al. 1995). Run-on analysis showed that transcription of CU P1 relative to rRN A was maintained at close to the wild-type level in kin28ts cells after $1 \mathrm{hr}$ at $37^{\circ} \mathrm{C}$ (Fig. 4A, cf. lane 2 with lane 4$)$. In contrast to CU P1, the run-on signal for ENO 2 was al most completely abolished at $37^{\circ} \mathrm{C}$. ACT1 and $\mathrm{CYH} 2$ run-on signals were al so significantly inhibited by Kin28 inactivation but to a lesser extent than ENO2 (Fig. $4 \mathrm{~A}, \mathrm{~B}$ ). At $37^{\circ} \mathrm{C}$, the ratios of $5^{\prime} \mathrm{CU} \mathrm{P} 1$ run-on transcription (corrected for $U$ content) to $5^{\prime}$ ENO2, CYH2, and ACT1 were 6.6, 1.8, and 6.0, respectively, in the KIN28 strain, compared to 146, 25, and 16 in the kin28ts strain.

Steady-state mRNA levels in kin28ts cells were measured by N orthern blot of samples isolated at intervals after shifting to $37^{\circ} \mathrm{C}$ (Fig. 4C). As expected, high levels of CUP1 mRNA were sustained for at least $2 \mathrm{hr}$ at the restrictive temperature, whereas $\mathrm{CYH} 2, \mathrm{HIS3}$, and $\mathrm{ACT} 1$ mRNAs rapidly decayed. Interestingly, HSP82 mRNA was actually induced by heat shock in the kin28ts mu- 
tant to the same degree as it was in the wild type (Fig. 4C). For reasons we do not understand, the peak HSP82 mRN A level was also maintained longer in the kin28ts mutant. These observations suggest that like CUP1, HSP82 can also be transcribed independently of the Kin28 kinase. This conclusion is subject to the reservation that it has not been confirmed by run-on analysis as signals from the HSP82 gene were very low.

These results show that transcription of different genes depends on the Kin28 kinase to different extents. After inactivation of Kin28, CUP1 and probably also HSP82 were transcribed at close to normal levels; ACT1 and $\mathrm{CYH} 2$ were transcribed at a much reduced level and transcription of ENO2 was not detectable.

\section{SRB4-independent transcription of CUP1}

We reasoned that transcription from a promoter that does not require the CTD may also not require the mediator. To test this idea, we asked whether Srb4, an essential subunit of mediator, is required for transcription of CUP1 using a temperature-sensitive mutant that inactivates the protein within $15 \mathrm{~min}$ at $37^{\circ} \mathrm{C}$ ( $\mathrm{T}$ hompson and Young 1995). Transcription of CUP1 was investigated by the run-on assay in srb4ts cells at $30^{\circ} \mathrm{C}$ and after $1 \mathrm{hr}$ at $37^{\circ} \mathrm{C}$. Remarkably, polymerase densities for the chromosomal CUP1 gene and the pRS316 CUP1-lacZCYC1 fusion gene were only slightly reduced when Srb4 was inactivated (Fig. 5A, cf. Iane 1 with lane 3). In a specificity control, no lacZ or CYC1 run-on signal was observed in cells with the pRS316 vector plasmid (lane 4). In contrast to CU P1, polymerase densities over ENO 2 (Fig. 5A, cf. lane 2 with lane 3 ) and ACT1 (P. Atadja and D. Bentley, unpubl.) were dramatically reduced at $37^{\circ} \mathrm{C}$ in srb4ts cells. The ratio of $5^{\prime}$ CU P1 run-on signal to $5^{\prime}$ ENO 2 in srb4ts cells was 2.7 at the permissive temperature compared to 14.1 at the restrictive temperature.

Consistent with the run-on results, Northern bl ot of steady-state mRN A from srb4ts cells showed that CU P1 transcripts remained high for at least $2 \mathrm{hr}$ at the restrictive temperature, whereas HIS3, ACT1, and ENO 2 transcripts decayed rapidly (Fig. 5C, lanes 4-6). In contrast, HSP82 mRNA was induced by heat shock equally in the srb4ts and isogenic SRB4 strains (Fig. 5C, cf. Iane 2 with lane 5). HSP82 mRN A also remained at a high level for a longer time in the srb4ts mutant than in the wild type.

We tested whether $\mathrm{Cu}^{2+}$ induction of CU P1 still operated in srb4ts cells at the restrictive temperature. The addition of $\mathrm{Cu}^{2+} 30 \mathrm{~min}$ after shifting the cells to $37^{\circ} \mathrm{C}$ caused a modest induction of the 0.6-kb CU P1 transcript (Fig. 5D, lanes 4-6) relative to that which occurs in the wild-type SRB4 strain (Fig. 5D, lanes 1-3). Interestingly, the $1.7-\mathrm{kb}$ dicistronic CUP1 transcript was specifically induced by $\mathrm{Cu}^{2+}$ at $37^{\circ} \mathrm{C}$ in the srb4ts mutant and not in the wild type (see arrow, Fig. 5D). In summary, the inducibility of HSP82 and CUP1 in srb4ts cells at the restrictive temperature suggests that some activation of transcription in response to stress stimuli can occur in the absence of this essential holoenzyme subunit.

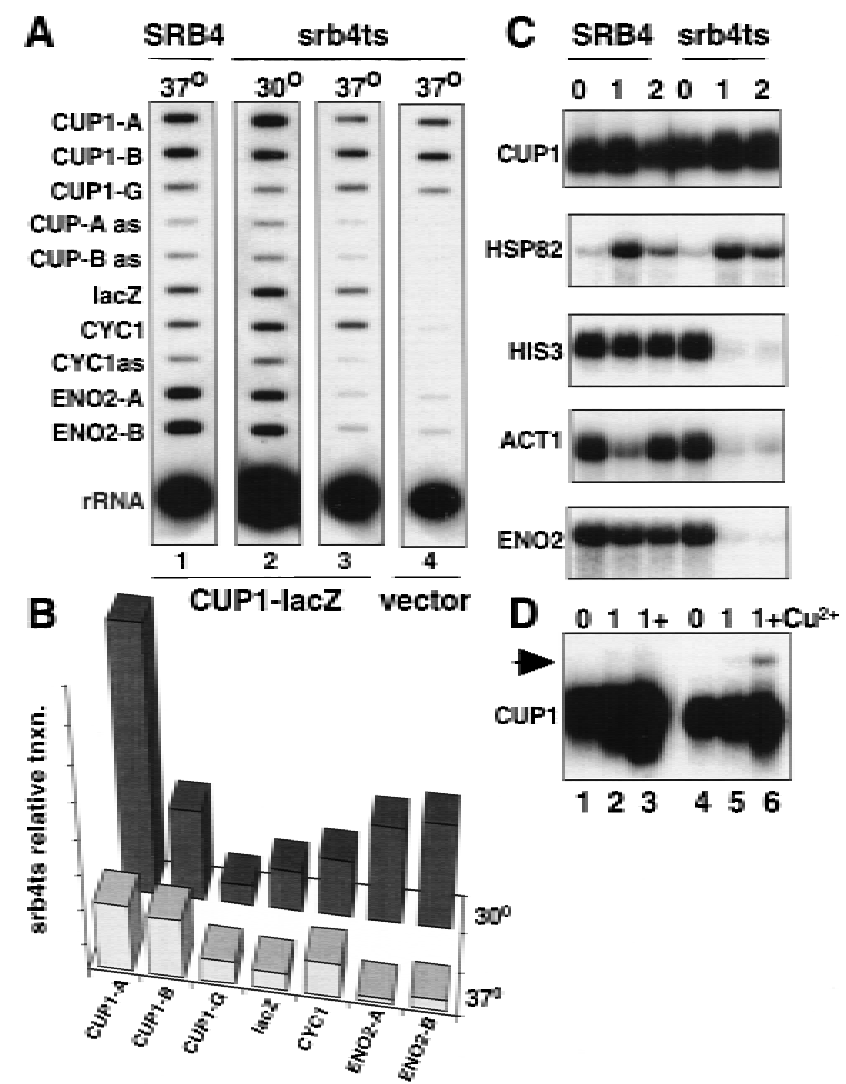

Figure 5. Srb4-independent transcription of CU P1 and HSP82. (A) Run-on transcription of strains Z579 (SRB4, lane 1) and Z628 (srb4ts, lanes 2-4). In lanes 1-3 the strains were transformed with the pRS316 CUP1-IacZ-CYC1 reporter plasmid and in lane 4 with pRS316 vector. $U$ contents of the hybridizing transcripts are CUP1A 56, CUP1-B 105, CUP1-G 138, IacZ 166, CYC1 99, EN O2-A 106, and EN O2-B 114. N ote the continued transcription of CU P1 and the CUP1-lacZ-CYC1 reporter gene in srb4ts cells at the restrictive temperature (lanes 3,4). Autoradiography was for 2 days. (B) Quantitation of run-on signals as in Fig. 2B. (C) Northern blots of mRNAs in Z579 (SRB4) and Z628 (srb4ts) strains at $30^{\circ} \mathrm{C}$ and after 1 and $2 \mathrm{hr}$ at $37^{\circ} \mathrm{C}$. N ote the induction of HSP82 mRNA after heat shock in the srb4ts strain. (D) N orthern blot analysis of CUP1 mRNA from Z579 (SRB4) and Z628 (srb4ts) at $30^{\circ} \mathrm{C}$ and after $1 \mathrm{hr}$ at $37^{\circ} \mathrm{C}$ plus and minus $\mathrm{Cu}^{2+}$, which was added $30 \mathrm{~min}$ after shifting to $37^{\circ} \mathrm{C}$ (lanes 3,6). N ote the induction of the 1.7-kb CU P1 mRN A (arrow) with $\mathrm{Cu}^{2+}$ at the restrictive temperature in the srb4ts strain (lane 6).

\section{Activation by the CUP1 UAS independent of Srb4}

To identify the sequence elements required for Srb4-independent transcription of CU P1, we anal yzed several 5' deletions of the CUP1 promoter in the plasmid pRS316 CUP1-lacZ-CYC1. Deletion to positions $-227,-169$, $-144,-129$, and -87 relative to the ATG eliminated almost completely expression of IacZ mRNA at both the permissive and restrictive temperatures (data not shown). The -227 deletion removes two Acel-binding sites and an HSF-binding site, but leaves the basal promoter region including the TATA box at -141 intact. Therefore, Srb4-independent transcription requires the 
CUP1 UAS and is not a property of the basal promoter alone. Our del etion analysis, however, does not identify individual binding sites that may be necessary for Srb4independent transcription.

To test whether the CU P1 UAS is sufficient for Srb4independent transcription, it was inserted as a 107-bp fragment in the forward and reverse orientations (designated $F$ and $R$ ) upstream of the basal CYC1 promoterlacZ fusion gene on multicopy plasmids. The plasmids were transformed into the isogenic SRB4 and srb4ts strains and lacZ transcripts were analyzed by N orthern blot. After shifting the cells to $37^{\circ} \mathrm{C}$ for $1 \mathrm{hr}$, there was a clear induction of lacZ mRNA in the srb4ts mutant, whereas the HIS3 control mRNA decayed rapidly (Fig. $6 A$, top, lanes 4,5 and 7,8). Little or no lacZ mRN A was detected from the CYC1-lacZ parent plasmid showing that expression is dependent on the CUP1 UAS (Fig. 6A, Ianes 1-3). When $\mathrm{Cu}^{2+}$ was added $30 \mathrm{~min}$ after shifting to $37^{\circ} \mathrm{C}$, a significant further induction of lacZ $\mathrm{mRN} A$ was observed $30 \mathrm{~min}$ later (Fig. 6A, top, lanes 5,6 and 8,9). The magnitude of IacZ mRN A induction in response to heat shock and $\mathrm{Cu}^{2+}$ was almost identical in the srb4ts and SRB4 wild-type strains (Fig. 6A, cf. top and bottom IacZ lanes). These results show that CU P1 UAS-dependent inducibletranscription of lacZ on a multicopy plasmid is almost completely independent of Srb4.

\section{$\triangle$ CTD Pol II responds to the CUP1 UAS}

We al so tested whether the CU PI UAS could function in the absence of the CTD. The UAS $\mathrm{CUPI}_{1}-\mathrm{CYC} 1-\mathrm{lacZ}$ plasmids were transformed into the rpb1-1 strain DBY 120 with pFL38, pFL38-RPB1, or pFL38-rpb1 $\Delta$ CTD. IacZ mRN A in cells grown at $30^{\circ} \mathrm{C}$ and $37^{\circ} \mathrm{C}$ was detected by $\mathrm{N}$ orthern blot (Fig. 6B). lacZ transcripts were induced approximatel y two- to fourfold in the pFL38-rpb1 $\Delta$ CTDcontaining strain after shifting to $37^{\circ} \mathrm{C}$ (Fig. 6B, lanes 4,5 and 7,8). These transcripts were dependent on expression of $\triangle$ CTD Pol II and were not present in the pFL38 vector control (Fig. 6B, bottom). Furthermore, this transcription by $\triangle$ CTD Pol II was dependent on the CUPI UAS, as very few transcripts of the CYC1-lacZ parent plasmid were detected (Fig. 6B, lane 1-3). At least as much lacZ mRN A was induced in response to a 1-hr heat shock at $37^{\circ} \mathrm{C}$ in $\triangle$ CTD Pol II-expressing cells as in the wild type (Fig. 6B, lanes 5,8, cf. top and middle). Interestingly, lacZ transcri pts made by $\triangle$ CTD Pol II migrated more diffusely than those made by wild-type Pol II. This al tered mobility may reflect a difference in RNA processing or degradation. CUP1 UAS-driven IacZ mRNA expression was not induced as much by $\mathrm{Cu}^{2+}$ in $\triangle$ CTD Pol II-expressing cells as in the wild type; however, clear activation was observed for the construct with the UAS in the reverse orientation (Fig. 6B, lanes 8,9). The induction of lacZ reporter gene mRNA in the absence of Srb4 or the CTD (Fig. 6) was al ways greater than that observed for CUP1 mRN A (Figs. 1A and 5D), possibly because of the higher stability of lacZ transcripts (Durrin et al. 1992). In summary, these results show that $\triangle C T D$ Pol II can carry out activated transcription dependent on the CUPI UAS.

\section{Discussion}

Pol II transcription in vivo without the CTD

The question of whether holoenzyme is universally re quired for Pol II transcription in vivo has not been previously explored in detail. We investigated transcription in budding yeast by Pol II that lacks the CTD and, therefore, is unable to assemble with medi ator into a conven-
Figure 6. The CUP UAS supports activated transcription independent of Srb4 and the CTD. (A) N orthern blots of lacZ and HIS3 control mRN A from Z628 (srb4ts, top) and Z579 (SRB4, bottom) strains transformed with Gal5-CYC1-lacZ (Ianes 1-3) and derivatives pJM 1505 (lanes 4-6) and pJM 1506 (lanes 7-9) with the CU P1 UAS in forward $(F)$ and reverse $(R)$ orientations (see diagram). RNA was isolated at $30^{\circ} \mathrm{C}(\mathrm{t}=0)$ and after $1 \mathrm{hr}$ at $37^{\circ} \mathrm{C}$ with or without the addition of $\mathrm{Cu}^{2+}(0.1 \mathrm{~mm})$, which was added after $30 \mathrm{~min}$ at $37^{\circ} \mathrm{C}$ (lanes $3,6,9$ ). $\mathrm{N}$ ote the induction of lacZ mRNA with heat shock and $\mathrm{Cu}^{2+}$ at the restrictive temperature in the srb4ts strain. (B) N orthern blot analysis of IacZ and $5 S$ rRNA control in DBY 120 (rpb1-1) transformed with pFL38rpb1 $\triangle$ CTD, pFL38-RPB1, or pFL38 vector as indicated. Each strain was also transformed with Gal5-CYC1-lacZ-TRP (lanes 1-3) or derivatives with the CUP1 UAS in forward $(F)$ and reverse (R) orientations (pJ M 1503, lanes 4-6; pJ M 1504, lanes 7-9). RN A was isolated from cultures treated as in $A$.
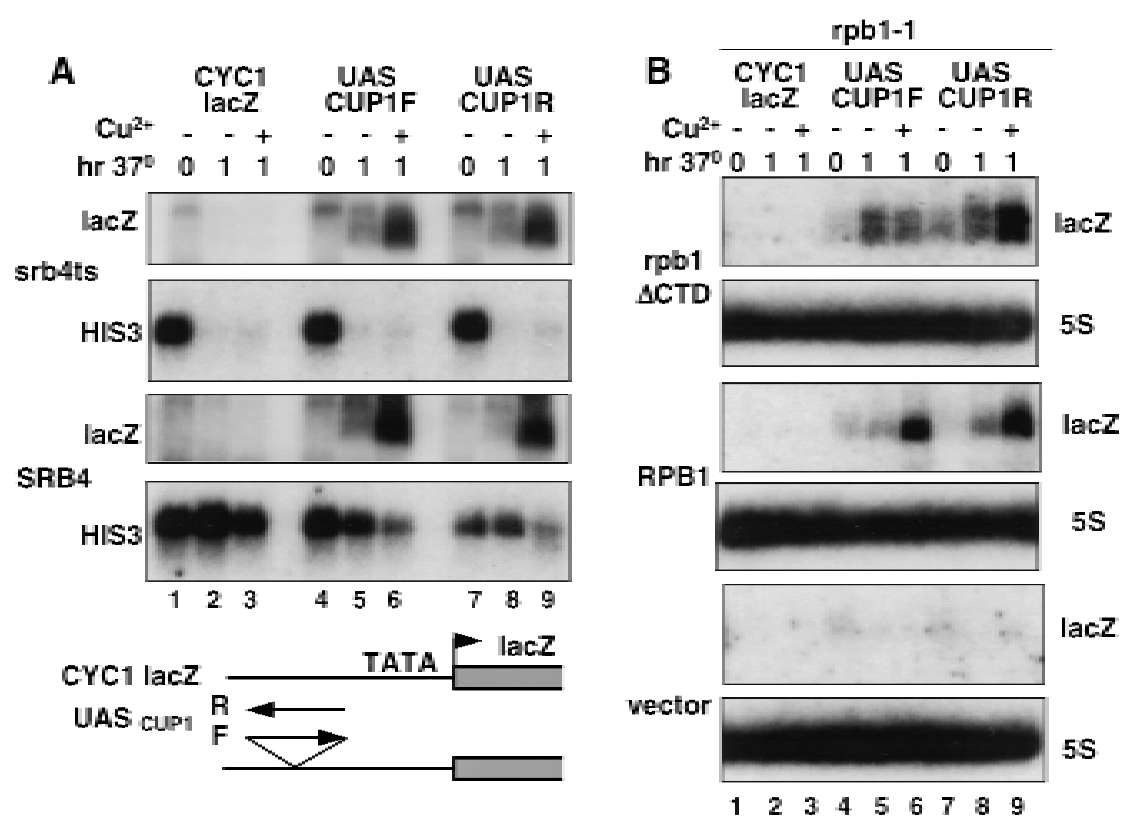
tional holoenzyme complex. These experiments used a yeast strain that expresses the temperature-sensitive rpb1-1 allele for the full-length Pol II large subunit (N onet et al. 1987a) and the CTD-del eted rpb1 $\Delta$ CTD allele. At the restrictive temperature, the only active Pol II molecules are those that lack the CTD. Under these conditions, $\triangle$ CTD Pol II was engaged on the CUP1 gene at significantly higher density than in the control strain without a Pol II expression plasmid (Fig. 2). It is conceivable that in the absence of the CTD, mediator makes alternative contacts with Pol II; however, this possibility is not consistent with the fact that CTD deletion prevents medi ator from working in an in vitro transcription system (M yers et al. 1998). Therefore, these observations strongly suggest that holoenzyme is not essential for Pol II to transcribe all protein-encoding genes in yeast. It remains to be determined whether other genes in addition to CUP1 can also be transcribed in vivo independently of the CTD.

The CTD has been implicated previously in the stimulation of transcriptional elongation by activators such as Drosophila HSF (O'Brien et al. 1994). We observed consistently that heat shock elevated the ratio of $3^{\prime}$-to-5' polymerase densities on CUP1 (cf. CUP1-B to CUP1-A run-on signals in Fig. 2A, lanes 3,4 and Fig. 5A, lanes 1,2). This apparent increase in the processivity of CU P1 transcription was prevented by CTD deletion (Fig. 2A,B) and Kin28 inactivation (Fig. 4A) but not by inactivation of Srb4 (Fig. 5A, cf. lane 2 with lanes 3,4). These results are consistent with the idea that the CTD and Kin28 enhance elongation in yeast (Akhtar et al. 1996). It is possible that yeast HSF, like its mammalian and D rosophila counterparts, is responsible for this enhancement of transcriptional processivity.

We do not know in what form $\triangle$ CTD Pol II transcribes CU P1 in vivo. It is possible that a holoenzyme complex independent of mediator with a distinct set of accessory proteins is involved. Such an alternative holoenzyme was described recently by Shi et al. (1997). It is al so possible that CTD-independent transcription is carried out by free core Pol II. This possi bility is consistent with the fact that $50 \%-95 \%$ of Pol II in yeast is estimated to exist in free form (Kim et al. 1994; Kol eske and Young 1994). The CTD is not essential for formation of preinitiation complexes containing mammalian Pol II, TFIIB, TFIID, and TFIIE/TFIIF on promoter DNA in vitro (Buratowski and Sharp 1990). Furthermore, Pol II without a CTD can initiate correctly at some promoters and can respond to certain activators in vitro (Zehring and Greenleaf 1990; Buermeyer et al. 1992; Kang and Dahmus 1993; Li and Kornberg 1994).

\section{Abnormal transcripts made by $\triangle$ CTD Pol II}

Paradoxically, transcription of CU P1 by $\triangle$ CTD Pol II occurs without accumulation of stable mRNA (Fig. 1A, lanes 11-15). We surmise that most of the transcripts made by CTD-deleted Pol II are unstable. This conclusion is supported by the observation that decay of CU P1 transcripts in rpbl $\Delta$ CTD cells at $37^{\circ} \mathrm{C}$ is blocked by de- letion of the XRN 1 gene, which encodes a 5'-3' exonuclease involved in mRN A turnover ( $\mathrm{Hsu}$ and Stevens 1993; Fig. 3). Unlike CUP1 mRNA, lacZ transcripts made by $\triangle$ CTD Pol II do accumulate (Fig. 6B), perhaps because they are exceptionally stable. One reason why most transcripts made by $\triangle$ CTD Pol II are unstable could be failure to receive a $5^{\prime}$ cap. In mammalian cells CTD truncation disrupts capping (McCracken et al. 1997a) and the yeast capping enzymes $\mathrm{Cegl}$ and $\mathrm{Abd} 1$ both bind directly to the phosphorylated CTD (Cho et al. 1997; McCracken et al. 1997a). Contrary to this expectation, most of the 1.7-kb CU P1 RN A made by $\triangle$ CTD Pol II was capped (perhaps post-transcriptionally) and was not stabilized by XRN1 deletion (S. McCracken, N. Fong, J.B. $\mathrm{McN}$ eil, unpubl.). Other possible reasons for the instability of transcripts made by $\triangle$ CTD Pol II include failure to engage appropriate RN A-binding proteins, inappropriate localization in the cell, or failure of other RN A processing steps.

In this regard, it is of interest that $3^{\prime}$ processing of CU P1 transcripts is less efficient when the gene is transcribed by CTD-del eted Pol II relative to wild-type causing the appearance of the dicistronic CUP1-YHR54C transcript (Fig. 1). Failure to cleave at the poly(A) site is characteristic of transcripts made by CTD-truncated Pol II in mammalian cells (McCracken et al. 1997b). These observations suggest that some degree of CTD-dependent coupling between $3^{\prime}$ processing and transcription occurs at CUP1; however, this phenomenon is not as general in yeast as it is in mammalian cells. Transcripts made by $\triangle$ CTD Pol II are cleaved efficiently at the CYC I poly(A) site (data not shown) and at the putative poly(A) site of the YHR54C gene (Fig. 1B, probe G). Furthermore, Pol I transcripts of the HIS4 gene are polyadenylated in yeast (Lo et al . 1998). Interestingly, a di cistronic mRN A was also made when the HIS4 gene was transcribed by Pol I (Lo et al. 1998). CTD-dependent 3' processing may be restricted to a particular subset of poly $(A)$ sites in yeast. Unusually long CUP1 transcripts have been observed previously in RN A processing and transport mutants (Forrester et al. 1992; Chanfreau et al. 1996). The 1.7-kb CU P1 RNA was also induced by $\mathrm{Cu}^{2+}$ specifically in the srb4ts mutant at $37^{\circ} \mathrm{C}$ (Fig. 5D). Defective $3^{\prime}$ processing at the CUP1 poly(A) site may, therefore, be a general characteristic of transcription by abnormal Pol II complexes.

\section{Diverse modes of transcriptional activation}

Pol II that lacks all of the CTD recognizes the CUP1 promoter and initiates transcription at the correct start sites in vivo (Fig. 1C). Consistent with the lack of a CTD requirement, transcription of CUP1 was also observed after inactivation of the CTD-associated mediator subunit Srb4 and the CTD kinase Kin28 (Figs. 4 and 5). Transcription of CUP1 and SSA 4 after inactivation of either Kin28 or Srb4 also has been reported by Lee and Lis (1998). The HSP82 gene was also expressed independently of Srb4 and Kin28 (Figs. 4 and 5). Dissection of the CUP1 promoter showed that it is the UAS and not the 
basal promoter elements that permit CTD-independent transcription (data not shown; Fig. 6B). In this respect the CUPI UAS contrasts sharply with the GALI and INO I UAS elements whose activity is severely inhibited by partial truncation of the CTD (Allison and Ingles 1989; Scafe et al. 1990). The CUP1 UAS fused to the CYC1 basal promoter could also stimulate a normal amount of transcription independent of Srb4 (Fig. 6A). The CU P1 gene differs from CYH2, ACT1, and ENO2, which have far more stringent requirements for Kin28 and Srb4 (Figs. 4 and 5; data not shown). Therefore, CUP1 and also HSP82 seem to be exceptional genes that can be transcribed independently of many holoenzyme components. The holoenzyme-independent activity of the CU P1 promoter is apparently not related to activation of the same promoter by histone depletion, which is independent of the UAS (Durrin et al. 1992).

These observations reinforce the principal that there are different requirements for components of the basal transcriptional machinery at different promoters in vivo. It was shown previously that TBP-associated factors (TAFs) are only essential for the function of a small subset of promoters in yeast (M oqtaderi et al. 1996; Walker et al. 1996) and that this requirement is di ctated by basal promoter elements (Shen and Green 1997).

The rel axed hol oenzyme requirement for activation by the CU P1 UAS is probably a consequence of the mechanism of activation by Acel or HSF, which bind to this element. HSF also stimulates transcription of the HSP82 gene which, like CU P1, is heat inducible in the absence of Srb4 and Kin28 (Figs. 4 and 5). These observations suggest that under some circumstances HSF can contribute to activation of transcription in the absence of intact holoenzyme. This ability may have evolved to allow transcription under stressful conditions where holoenzyme is disrupted or limiting. There is much support for the model that transcriptional activation works by recruitment of holoenzyme to promoters through proteinprotein contacts with sequence-specific transcription factors (Ptashne and Gann 1997). The existence of a holoenzyme-independent mode of activation by the CU P1 UAS shows that this model does not apply in all cases and that diverse mechanisms of activation may operate at different promoters.

\section{Materials and methods}

Yeast strains and growth conditions

Yeast cultures (Table 1) were grown in synthetic complete (SC) medium plus $2 \%$ glucose without tryptophan or uracil as necessary, to maintain plasmid DNAs. Copper induction was by addition of copper sulfate to $0.1 \mathrm{~mm}, 30 \mathrm{~min}$ after shifting to the restrictive temperature. The TRP1 and XRN1 genes in Y 260 were disrupted by one-step integration of homologous fragments containing URA 3 flanked by hisG repeats. U ra- derivatives were then selected on FOA containing plates.

\section{Northern blotting and RNase protection}

For Northern blots total RNA prepared by the hot phenol method $(20 \mu \mathrm{g})$ was el ectrophoresed on $1.2 \%$ formal dehyde or on $1 \% 0.5 \times \mathrm{TBE}$ nondenaturing agarose gels and transferred to Genescreen (N ew England Nuclear). Antisense riboprobes for CUP1, SSA1, CYH2, ACT1, ENO2, HIS3, HSP82, and lacZ mRNA and 5S rRNA were made from pWF1, pBS-SSA1, pBSCYH2, pVZ-ACT1, pBS-EN O2, pVZ-HIS3, pBS-HSP82, pVZlacZ, and pBS-5S, respectively. For RN ase protection, $20 \mu \mathrm{g}$ of RNA was hybridized overnight to antisense probes in $0.4 \mathrm{M}$ $\mathrm{N} \mathrm{aCl}, 0.5 \mathrm{~mm}$ EDTA , $20 \mathrm{~mm}$ PIPES (pH 6.4), 80\% formamide at $50^{\circ} \mathrm{C}$. RN ase digestion was in $0.3 \mathrm{M} \mathrm{N} \mathrm{aCl}, 10 \mathrm{~mm}$ Tris (pH 7.5), $5 \mathrm{~mm}$ EDTA, $5 \mu \mathrm{g} / \mathrm{ml}$ RN ase T 1, $1.0 \mu \mathrm{g} / \mathrm{ml}$ RN ase $A$ for $30 \mathrm{~min}$ at $37^{\circ} \mathrm{C}$.

\section{Hybrid selection}

Two micrograms of EcoRI-digested, heat-denatured pBS-5S, and $1 \mu \mathrm{g}$ of single-stranded M $13 \mathrm{mp19}$ CUP1-A or CUP1-G were mixed and slot-blotted onto Genescreen (Dupont). One hundred micrograms of total yeast RNA was incubated overnight with the filters at $65^{\circ} \mathrm{C}$ in $0.4 \mathrm{ml}$ of $0.4 \mathrm{M} \mathrm{NaCl}, 0.5 \mathrm{~mm}$ EDTA, $20 \mathrm{~mm}$ PIPES (pH 6.4). The filters were washed two times at $60^{\circ} \mathrm{C}$ in $1 \times$ SSC and $1 \%$ SDS and then heated at $100^{\circ} \mathrm{C}$ for 10 min in $\mathrm{H}_{2} \mathrm{O}$. Ten micrograms of total Escherichia coli RNA was added and the eluted RN A was precipitated with ethanol. CUP1-A and 5S antisense probes were used for RN ase protection of selected RNA.

Transcriptional run-on analysis and M13 probes

Run-on reactions were performed as described previously in Sarkosyl-permeabilized cells (Elion and Warner 1986; A khtar et al. 1996). All run-on probes were single-stranded M 13s. The data were quantified by Phosphorlmager (M olecular Dynamics). All values were normalized for $U$ content and cell number and are expressed in arbitrary units.

M 13 CUP1-A-G contain fragments of the CU P1 repeat generated by PCR. The sequences in each clone numbered according to Karin et al. (1984) are as follows: A 1454-1714; B 1710-20; C 25-392; D 362-675; E 658-888; F 886-1117; G 1076-1456. The PCR primers were A, 5'-GCCGGGATCCGTGCAATATCATATAGAAGTCATC and 5'-CGGCGGATCCCAGAGCAGCATGACTTCTTGG; B, 5'-GCCGGGATCCGGGAAATGAAACGAATAGTC and 5'-CGGCGGATCCAGCAGCGGGTA-

Table 1. Yeast strains and growth conditions

\begin{tabular}{|c|c|c|}
\hline Strain & Genotype & Source \\
\hline Y260 & MATa, ura3-52 rpb1-1 & N onet et al. (1987a) \\
\hline DBY 120 & MATa ura3-52 rpb1-1 trp1::hisG & isogenic with Y 260 (this study) \\
\hline DBY 121 & MATa, ura3-52 rpb1-1 trp1::hisG $\Delta$ xrn1::hisG & isogenic with Y260 (this study) \\
\hline Z579 & MATa his3 2200 leu2-3,112 ura3-52 srb4 $22:: H I S 3$ [pRY2844 (LEU 2 CEN SRB4)] & Thompson and Young (1995) \\
\hline Z628 & MATa his3 200 leu2-3,112 ura3-52 srb4 $2:: H I S 3$ [pRY2882 (LEU 2 CEN srb4-138)] & Thompson and Young (1995) \\
\hline GF262 & MAT $\alpha$ leu2 trp1 ura3 his3 & Valay et al. (1993) \\
\hline kin28ts3 & MAT $\alpha$ leu2 trp1 ura3 his3 kin28ts3 & Valay et al. (1993) \\
\hline
\end{tabular}


CCATGAAT; C, 5'-CGGCGGATCCTATCTCCGATACCTGCCTC and 5'-CGGCGGATCCTTTGCACATCTTTCAGAG; D, 5'-CGGCGGATCCGACCTCGAACTCTGAAAGATGTG and 5'-CGGCGGATCCAAAATCTTGTCATGAATC; E, 5'CGGCGGATCCGATTCATGACAAGATTTTGG and 5'-GCCGGGATCCGAGAACATTTTTGTTCTTCG CC; F, 5'-CGGCGGATCCTCTTGAAATTCCCCGTTAGTG and 5'-GCCGGGATCCGAACATATGCACGTATAGCGCCC; G, 5'-CGGCGGATCCCATTACCGACATTTGGG and 5'-CGGCGGATCCACTAACAAGAAGATATTATAATGC.

CYC1 sense and antisense probes were derived from a 321-bp PCR fragment comprising bases +290 to +610 relative to the ATG in the HindlII-Sall site of M13mp18 and M13mp19, re spectively. The PCR primers used were 5'-GCGGAAGCTTGAAACGACTTAATTACCTACTTG and 5'-CGCCCTCGAGCTTGCAAATTAAAGCCTTCGAGCG.

CYH2 sense and antisense probes contain the 378-bp PCR fragment derived from the CDNA in pAS2 (Clontech), comprising -23 to the EcoRI site at +355 relative to the ATG, inserted into the EcoRI-Sall sites of M 13mp18 and M13mp19, respectively. The forward PCR primer was 5'-GGCGGTCGACAACAATCATCCAACTAATC.

ENO2-A is a PCR fragment comprising bases -32 to +385 relative to the ATG in M13mp19. The PCR primers were $5^{\prime}-$ ATGGATCCAAGCAACTAATACTATAAC and 5'-ATCTCGAGGGACGTTCTTTTCAGCAGC.

EN O2-B is a PCR fragment comprising bases +888 to +1302 relative to the ATG cloned into $M 13 \mathrm{mp} 19$. The $P C R$ primers were 5'-ATGGATCCATTTGCTGAAGATGAC and 5'-ATCTCGAGCACCGTGGTGG AGTTTTCAC.

ACT 1 is a 382 -bp PCR fragment comprising bases +1407 to + 1787 relative to the ATG cloned in M 13mp18. The PCR primers were 5'-CCGGATCCATCTATCGTTCACCACAAG and 5'CCGAATTCTCCCAAGA AGGGCAATTGCA.

The lacZ (L2) and 35S rRN A M 13 probes have been described (Akhtar et al. 1996).

\section{Plasmids}

pFL38 is a CEN -based U RA3 plasmid (Bonneaud et al. 1991).

pFL38-RPB1 was made by inserting a 6042 bp EcoRI-Pstl fragment of RPB1 into pFL38 after destroying the HindlII site in the polylinker.

pFL38-rpb1 $\triangle$ CTD was made by replacing the 885-bp BsiWIHindlII fragment in pFL38-RPB1, which contains codons 1510 through the carboxyl terminus, and $230 \mathrm{bp}$ of $3^{\prime}$ flanking sequence with a BsiWI-HindIII cut PCR fragment encoding residues 1510 to 1533 . Codon 1533 is at position 4 of the first heptad repeat. Amino acids SFKW were inserted as a result of a PCR error after codon 1533 and before the termination codon.

pRS314 CUP1-lacZ-CYC1 and pRS316 CUP1-lacZ-CYC1 contain the CUP1 promoter ( -394 to +37 relative to the major transcriptional start site), IacZ (codons $10-1024)$ and zeo coding regions, and the CYC1 $3^{\prime}$ processing signal (bases +336 to +610 relative to the $\mathrm{CYC} 1 \mathrm{ATG}$ ) cloned between the $\mathrm{Notl}$ and $\mathrm{Kpnl}$ sites of pRS314 (CEN, TRP1) and pRS316 (CEN , U RA3) (Sikorski and Hieter 1989), respectively. The lacZ-zeor-CYC1 cassette was derived from pUT357 (Cayla, Toulouse, France).

Gal5-CY C1-lacZ (2 mum, U RA3) was described (Akhtar et al . 1996).

Gal5-CYC1-lacZ-TRP1 was derived from Gal5-CYC1-lacZ as follows. The URA3 marker was excised partially by Stul digestion and replaced with a blunt-ended BglII TRP1 fragment derived from pFL35 (Bonneaud et al. 1991).

pJM 1503 and pJM 1504 are derivatives of Gal5-CYC1-lacZTRP1 with insertion of a 107-bp PCR fragment that includes the
CUP1 UAS (bases 1255-1362 according to Karin et al. 1984) inserted into the Xhol site between the Gal4-binding sites and the $C Y C 1$ promoter in the forward and reverse orientations, respectively. The PCR primers were 5'-GGCGGTCGACATTTTTGCTGTCAGTCAC and 5'-GGCGGTCGACGTCTTTTTTGCTGGAACGGTTC.

pJM 1505 and pJM 1506 were made by insertion of the CUP1 UAS fragment into Gal5-CYC1-IacZ (URA3) in forward and reverse orientations, respectively.

pBS-5S contains a 245-bp fragment of yeast 5S rRN A (with 40 bases of $5^{\prime}$ and 84 bases of $3^{\prime}$ flank) (Challice and Segall 1989) in pBSKS-.

pBS-HSP82 is a 515-bp PCR fragment $(-313$ to +202 relative to the HSP82 ATG) cloned into the BamHI-Xhol site of pBSKS-. The primers used were 5'-CGGCGGATCCTCATACGCTTGTCACATATTGTTC and 5'-GCCGCTCGAGTGATTCTAATAAAGAGATCTGG.

pBS-SSA 1 is a 395-bp PCR fragment ( -191 to +204 relative to the SSA 1 ATG) cloned into the BamHI-Xhol site of pBSKS-. The primers used were 5 '-CGGCGGATCCTGATCGTTTCGAGGACTTCAAGG and 5'-GCCGCTCGAGCGTCGAAAACGGTATTCGAAGG.

pBS-CYH2 contains the same 378-bp CYH2 cDN A fragment used for the M 13 clones (see above) inserted into the EcoRI-Sall site of pBSKS-.

pBS-EN O2 contains the same PCR fragment as M 13 EN O2-A (see above) in the BamHI-Sall site of pBSKS-.

pBS-CUP1-A, B, and G (see Fig. 1D) contain PCR fragments described above for the respective $M 13$ s cloned into pBSKS-

pVZ-ACT 1, pVZ-lacZ, pVZ-HIS3 (Akhtar et al. 1996), and the CUP1 clone pWF1 (Forrester et al. 1992) have been described.

\section{Acknowledgments}

We thank P. Atadja for his help in starting this project. We thank J. Segall, S. Dalton, M. Wickens, D. Jansma, J. Friesen, R. Young, and G. Faye for gifts of plasmids and yeast strains. We thank S. M cCracken, J. Greenblatt, and L. Harrington for comments on the manuscript, S. McCracken and N. Fong for technical help, and M. Luchico and E. Schaeffer for expert secretarial and computing assistance. We are grateful to J. Lis for communicating data before publication. This work was supported in part by a grant from the M edical Research Council of Canada to D.B.

The publication costs of this article were defrayed in part by payment of page charges. This article must therefore be hereby marked "advertisement" in accordance with 18 USC section 1734 solely to indicate this fact.

\section{References}

Akhtar, A., G. Faye, and D. Bentley. 1996. Distinct activated and non-activated RNA polymerase II complexes in yeast. EMBO J. 15: 4654-4664.

Allison, L.A. and C.J. Ingles. 1989. Mutations in RN A polymerase II enhance or suppress mutations in GAL4. Proc. Natl. Acad. Sci. 86: 2794-2798.

Bonneaud, N., K.-O. Ozier, G.Y. Li, M. Labouesse, S.-L. Minvielle, and F. Lacroute. 1991. A family of Iow and high copy replicative, integrative and single-stranded S. cerevisiae/E. coli shuttle vectors. Yeast 7: 609-615.

Buermeyer, A.B., N .E. Thompson, L.A. Strasheim, R.R. Burgess, and P.J. Farnham. 1992. The HIP1 initiator element plays a role in determining the in vitro requirement of the dihydro- 
folate reductase gene promoter for the $\mathrm{C}$-terminal domain of RN A polymerase II. Mol. Cell. Biol. 12: 2250-2259.

Buratowski, S. and P.A. Sharp. 1990. Transcription initiation complexes and upstream activation with RN A polymerase II lacking the $\mathrm{C}$-terminal domain of the largest subunit. Mol. Cell. Biol. 10: 5562-5564.

Carlson, M. 1997. Genetics of transcriptional regulation in yeast: Connections to the RNA polymerase II CTD. Annu. Rev. Cell Dev. Biol. 13: 1-23.

Challice, J.M . and J. Segall. 1989. Transcription of the 5 S rRN A gene of Saccharomyces cerevisiae requires a promoter element at +1 and a 14-base pair internal control region. J. Biol. Chem. 264: 20060-20067.

Chanfreau, G., S.M. Noble, and C. Guthrie. 1996. Essential yeast protein with unexpected similarity to subunits of mammalian cleavage and polyadenylation specificity factor (CPSF). Science 274: 1511-1514.

Cho, E.-J., T. Takagi, C. M oore, and S. Buratowski. 1997. mRN A capping enzyme is recruited to the transcription complex by phosphorylation of the RNA polymerase II carboxy-terminal domain. Genes \& Dev. 11: 3319-3326.

Cismowski, M., G. Laff, M. Solomon, and S. Reed. 1995. KIN28 encodes a C-terminal domain kinase that controls mRNA transcription in Saccharomyces cerevisiae but lacks cyclindependent kinase-activating kinase (CAK) activity. Mol. Cell. Biol. 15: 2983-2992.

Dahmus, M.E. 1996. Reversible phosphorylation of the C-terminal domain of RNA polymerase II. J. Biol. Chem. 271: 19009-19012.

Durrin, L.K., R.K. Mann, and M. Grunstein. 1992. Nucleosome loss activates cupl and his3 promoters to fully induced levels in the yeast Saccharomyces cerevisiae. Mol. Cell. Biol. 12: 1621-1629.

Elion, E.A. and J.R. Warner. 1986. An RNA polymerase I enhancer in Saccharomyces cerevisiae. Mol. Cell. Biol. 6: 2089-2097.

Farrell, S., N. Simkovich, Y. Wu, A. Barberis, and M. Ptashne. 1996. Gene activation by recruitment of the RN A polymerase II holoenzyme. Genes \& Dev. 10: 2359-2367.

Forrester, W., F. Stutz, M. Rosbash, and M. Wickens. 1992. Defects in mRNA 3 '-end formation, transcription initiation, and mRNA transport associated with the yeast mutation prp20: Possible coupling of mRNA processing and chromatin structure. Genes \& Dev. 6: 1914-1926.

Gerber, H.P., M. Hagmann, K. Seipel, O. Georgiev, M.A. West, Y. Litingtung, W. Schaffner, and J.L. Corden. 1995. RNA polymerase II C-terminal domain required for enhancerdriven transcription. Nature 374: 660-662.

Hengartner, C.J., C.M. Thompson, J. Zhang, D.M. Chao, S.M. Liao, A.J. Koleske, S. Okamura, and R.A. Young. 1995. Association of an activator with an RNA polymerase II holoenzyme. Genes \& Dev. 9: 897-910.

Hsu, C.L. and A. Stevens. 1993. Yeast cells lacking 5' $\rightarrow$ 3' exoribonuclease 1 contain mRN A species that are poly(A) de ficient and partially lack the 5' cap structure. Mol. Cell. Biol. 13: 4826-4835.

Kang, M.E. and M.E. Dahmus. 1993. RNA polymerase IIA and polymerase IIO have distinct roles during transcription from the TATA-less murine dihydrofolate reductase promoter. J. Biol. Chem. 268: 25033-25040.

Karin, M., R. Najarian, A. Haslinger, P. Valenzuela, J. Welch, and S. Fogel. 1984. Primary structure and transcription of an amplified genetic locus: The CUP1 locus of yeast. Proc. Natl. Acad. Sci. 81: 337-341.

Kim, Y.J., S. Bjorklund, Y. Li, M.H. Sayre, and R.D. Kornberg. 1994. A multiprotein mediator of transcriptional activation and its interaction with the C-terminal repeat domain of RNA polymerase II. Cell 77: 599-608.

Koleske, A.J. and R.A. Young. 1994. An RNA polymerase II holoenzyme responsive to activators. Nature 368: 466-469.

Kolodziej, P.A., N. Woychik, S.M. Liao, and R.A. Young. 1990. RNA polymerasell subunit composition, stoichiometry, and phosphorylation. Mol. Cell. Biol. 10: 1915-1920.

Lee, D.-K. and J. Lis. 1998. Transcriptional activation independent of TFIIH kinase and the RN A polymerase II mediator in vivo. Nature 393: 389-392.

Lee, J.M. and A.L. Greenleaf. 1997. Modulation of RNA polymerase II elongation efficiency by C-terminal heptapeptide repeat domain kinase I. J. Biol. Chem. 272: 10990-10993.

Li, Y. and R.D. Kornberg. 1994. Interplay of positive and negative effectors in function of the $\mathrm{C}$-terminal repeat domain of RN A polymerase II. Proc. Natl. Acad. Sci. 91: 2362-2366.

Liao, S.M., I.C. Taylor, R.E. Kingston, and R.A. Young. 1991. RNA polymerase II carboxy-terminal domain contributes to the response to multiple acidic activators in vitro. Genes \& Dev. 5: 2431-2440.

Lo, H.J., H.K. Huang, and T.F. Donahue. 1998. RN A polymerase I-promoted HIS4 expression yields uncapped, polyadenylated mRNA that is unstable and inefficiently translated in Saccharomyces cerevisiae. Mol. Cell. Biol. 18: 665-675.

M al donado, E., R. Shiekhattar, M. Shel don, H. Cho, R. Drapkin, P. Rickert, E. Lees, C. Anderson, S. Linn, and D. Reinberg. 1996. A human RNA polymerase II associated complex with SRB and DN A-repair proteins. Nature 381: 86-89.

McCracken, S., N . Fong, E. Rosonina, K. Yankulov, G. Brothers, D. Siderovski, A. Hessel, S. Foster, Amgen EST Program, S. Shuman, and D. Bentley. 1997a. 5'-Capping enzymes are targeted to pre-mRNA by binding to the phosphorylated carboxy-terminal domain of RNA polymerase II. Genes \& Dev. 11: 3306-3318.

McCracken, S., N. Fong, K. Yankulov, S. Ballantyne, G.H. Pan, J. Greenblatt, S.D. Patterson, M. Wickens, and D.L. Bentley. 1997b. The C-terminal domain of RNA polymerase II couples messenger RN A processing to transcription. Nature 385: 357-361.

Moqtaderi, Z., Y. Bai, D. Poon, P.A. Weil, and K. Struhl. 1996. Tbp-associated factors are not generally required for transcriptional activation in yeast. Nature 383: 188-191.

Myers, L., C. Gustafson, D. Bushnell, M. Lui, H. ErdumentBromage, P. Tempst, and R. Kornberg. 1998. The M ed proteins of yeast and their function through the RNA polymerase II carboxy-terminal domain. Genes \& Dev. 12: 45-54.

N onet, M.L. and R.A. Young. 1989. Intragenic and extragenic suppressors of mutations in the heptapeptide repeat domain of Saccharomyces cerevisiae RNA polymerase II. Genetics 123: 715-724.

N onet, M., C. Scafe, J. Sexton, and R. Young. 1987a. Eukaryotic RNA polymerase conditional mutant that rapidly ceases mRN A synthesis. Mol. Cell. Biol. 7: 1602-1611.

Nonet, M., D. Sweetser, and R.A. Young. 1987b. Functional redundancy and structural polymorphism in the large subunit of RNA polymerase II. Cell 50: 909-915.

O'Brien, T., S. Hardin, A. Greenleaf, and J.T. Lis. 1994. Phosphorylation of RNA polymerase II C-terminal domain and transcriptional elongation. Nature 370: 75-77.

Ossipow, V., J.P. Tassan, E.A. Nigg, and U. Schibler. 1995. A mammalian RNA polymerase II holoenzyme containing all components required for promoter-specific transcription initiation. Cell 83: 137-146.

Pan, G., T. Aso, and J. Greenblatt. 1997. Interaction of el ongation factors TFIIS and elongin A with a human RNA polymerase II holoenzyme capable of promoter-specific initia- 
tion and responsive to transcriptional activators. J. Biol. Chem. 272: 24563-24571.

Ptashne, M. and A. Gann. 1997. Transcriptional activation by recruitment. Nature 386: 569-577.

Scafe, C., D. Chao, J. Lopes, J.P. Hirsch, S. Henry, and R.A. Young. 1990. RNA polymerase II C-terminal repeat influences response to transcriptional enhancer signals. Nature 347: 491-494.

Shen, W.C. and M .R. Green. 1997. Y east TAF(II)145 functions as a core promoter selectivity factor, not a general coactivator. Cell 90: 615-624.

Shi, X.M., M.P. Chang, A.J. Wolf, C.H. Chang, A.A. Frazerabel, P.A. Wade, Z.F. Burton, and J.A. Jaehning. 1997. Cdc73p and paf1p are found in a novel RNA polymerase II-containing complex distinct from the Srbp-containing holoenzyme. Mol. Cell. Biol. 17: 1160-1169.

Sikorski, R. and P. Hieter. 1989. A system of shuttle vectors and yeast host strains designed for efficient manipulation of DNA in Saccharomyces cerevisiae. Genetics 122: 19-27.

Silar, P., G. Butler, and D.J. Thiele. 1991. Heat shock transcription factor activates transcription of the yeast metallothionein gene. Mol. Cell. Biol. 11: 1232-1238.

Stargell, L.A. and K. Struhl. 1995. The TBP-TFIIA interaction in the response to acidic activators in vivo. Science 269: 75-78.

Svejstrup, J.Q., Y. Li, J. Fellows, A. Gnatt, S. Bjorklund, and R.D. Kornberg. 1997. Evidence for a mediator cycle at the initiation of transcription. Proc. Natl. Acad. Sci. 94: 6075-6078.

Thiele, D.J. and D.H. Hamer. 1986. Tandemly duplicated upstream control sequences mediate copper-induced transcription of the Saccharomyces cerevisiae copper-metallothionein gene. Mol. Cell. Biol. 6: 1158-1163.

Thompson, C.M. and R.A. Young. 1995. General requirement for RNA polymerase II holoenzymes in vivo. Proc. Natl. Acad. Sci. 92: 4587-4590.

Thompson, C.M., A.J. Koleske, D.M. Chao, and R.A. Young. 1993. A multisubunit complex associated with the RNA polymerase II CTD and TATA-binding protein in yeast. Cell 73: 1361-1375.

Valay, J.G., M. Simon, and G. Faye. 1993. The kin28 protein kinase is associated with a cyclin in Saccharomyces cerevisiae. J. Mol. Biol. 234: 307-310.

Valay, J.-G., M. Simon, M.-F. Dubois, O. Bensaude, C. Facca, and G. Faye. 1995. The KIN28 gene is required for RNA polymerase II mediated transcription and phosphorylation of the Rpb1p CTD. J. Mol. Biol. 249: 535-544.

Walker, S.S., J.C. Reese, L.M. A pone, and M.R. Green. 1996. Transcription activation in cells lacking TAF(II)s. Nature 383: 185-188.

West, M. and J. Corden. 1995. Construction and analysis of yeast RNA polymerase II CTD deletion and substitution mutations. Genetics 140: 1223-1233.

Wilson, C.J., D.M. Chao, A.N. Imbalzano, G.R. Schnitzler, R.E. Kingston, and R.A. Young. 1996. RN A polymerase II holoenzyme contains Swi/Snf regulators involved in chromatin remodeling. Cell 84: 235-244.

Yang, W.M., W. Gahl, and D. Hamer. 1991. Role of heat shock transcription factor in yeast metallothionein gene expression. Mol. Cell. Biol. 11: 3676-3681.

Zehring, W.A. and A.L. Greenleaf. 1990. The carboxyl-terminal repeat domain of RNA polymerase II is not required for transcription factor Spl to function in vitro. J. Biol. Chem. 265: 8351-8353. 


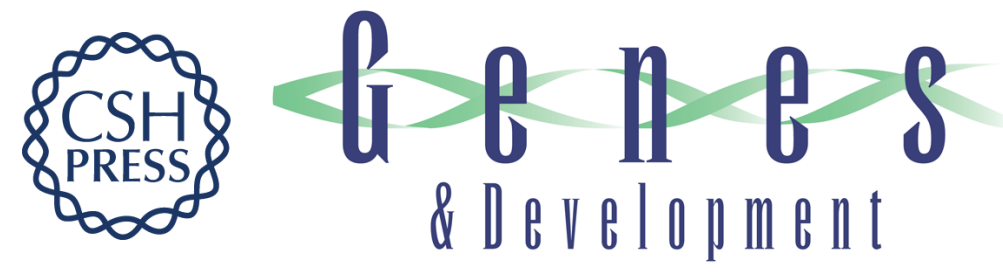

\title{
Activated transcription independent of the RNA polymerase II holoenzyme in budding yeast
}

\author{
J. Bryan McNeil, Helga Agah and David Bentley
}

Genes Dev. 1998, 12:

Access the most recent version at doi:10.1101/gad.12.16.2510

$\begin{array}{ll}\text { References } & \begin{array}{l}\text { This article cites } 57 \text { articles, } 36 \text { of which can be accessed free at: } \\ \text { http://genesdev.cshlp.org/content/12/16/2510.full.html\#ref-list-1 }\end{array}\end{array}$

License

Email Alerting Receive free email alerts when new articles cite this article - sign up in the box at the top Service right corner of the article or click here.

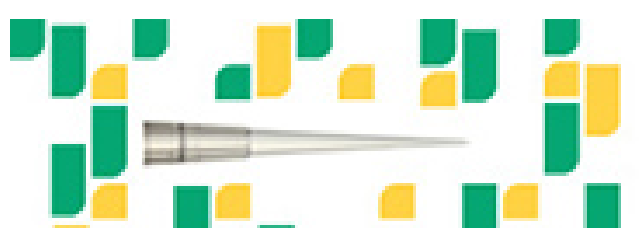

Focused on your science. 